\title{
Description of seven new Tinodes species from Asia (Trichoptera: Psychomyiidae)
}

\author{
KJELL ARNE JOHANSON ${ }^{1}$ \& JÁNOS OLÁH ${ }^{2}$ \\ ${ }^{1}$ Swedish Museum of Natural History, Entomology Department, Box 50007, SE-104 05 Stockholm, Sweden. \\ E-mail: kjell.arne.johanson@nrm.se \\ ${ }^{2}$ Department of Environmental Management, Tessedik College, Szarvas, Hungary. Residence Address: I. kk. 10, H-5540 Szarvas, Hun- \\ gary.E-mail: saker@szarvasnet.hu
}

\begin{abstract}
Seven new Tinodes species are described from South-East Asia. Tinodes kemnounga, new species, Tinodes caolana, new species, Tinodes gapbona, new species, and Tinodes dactringa, new species are described from Vietnam. Tinodes samkuca, new species, Tinodes kebala, new species, and Tinodes suksa, new species are described from Peninsular Malaysia.
\end{abstract}

Key words: Trichoptera, Psychomyiidae, Tinodes, new species, Oriental Region, Malaysia, Vietnam

\section{Introduction}

Eighty-seven species of the psychomyiid genus Tinodes have been recorded from the Oriental Region (Morse 1999). The other area rich in Tinodes species is the West Palaearctic Region from where 85 species have been recorded (Malicky 2004a). The high diversity in the Oriental and West Palaearctic Regions is especially evident when compared to the Nearctic Region that has 13 recorded extant species, and the East Palaearctic Region that has 7 recorded species. The genus has not been recorded from the Neotropical Region, and three species are known from the Australian Region, of which two species are from Papua New Guinea. The Afrotropical Region has 23 described Tinodes species restricted to areas south of Sahara (Johanson \& Oláh 2007). The first Tinodes species being described from the Oriental Region was T. flavopunctatus Ulmer 1910 from Java, and more species were subsequently described in the 1920's, i.e. T. retirtus Ulmer 1927 and T. formosae Iwata 1928 from Taiwan, and in the 1930's, i.e. T. pullulans Navás 1932 from India, T. adjunctus Banks 1937 and T. tagalicus Banks 1937 from the Philippines, and T. sumatrensis Ulmer 1930 from Sumatra. The largest addition to the knowledge on the Oriental Tinodes species was given by Schmid (1972) who described 23, mainly Indian species. Altogether 12 species were described from Thailand (Malicky \& Chantaramongkol 1989, 1993, 1996, 2003). Also the Philippines and Indonesia have 12 species recorded each (Banks 1937, Mey 1990, 1995, 1998a, b and Ulmer 1910, 1930, 1951, Malicky 1995, 1998, 2004b, respectively).

The 5 known Vietnamese Tinodes species, T. apteryx, T. meleagris, T. micrapteryx, T. physetes and T. triomdys, were described by Malicky (1995) and collected from a single locality about $80 \mathrm{~km}$ NW Hanoi in May and June 1995. The Tinodes fauna of Malaysia has been described by Kimmins (1955) (T. igok, T. silvicolus and T. tricalcaratus from Sarawak), Schmid (1972) (T. multispinodus from Pahang), Malicky (1995) (T. anakkunci from Perak) and Johanson (2001) (T. malickyi and T. fulvus from Sabah). 


\section{Material and methods}

Three of the new Tinodes species from Vietnam are described based on a single male each. The fourth new species, T. dactringa, is represented by 9 males and 6 females. All specimens were sampled by János Oláh in May 1987 and in October 1986 and 1988, and all 4 species are found in different provinces. The 3 new species from Malaysia were collected in the sultanate Perak of the Peninsular Region by G. S. Robinson in SeptemberNovember 1993, and by K. R. Truck in the sultanate Pahang in November 1981. The type material of these comprises a single male, except $T$. suksa which is represented also by 11 male paratypes. All holotypes are stored in $80 \%$ alcohol and deposited in Oláh Private Collection (OPC). Paratypes are stored in $80 \%$ alcohol in (OPC) and in the Swedish Museum of Natural History, Stockholm (NRM). Techniques and procedures used in the preparation and examination of specimens are those outlined by Oláh et al. (2008). The terminology applied to the male genitalia follows Nielsen (1957). All descriptions are based only on the male genitalia.

\section{Systematics}

\section{Tinodes kemnounga, new species}

Fig. 1-3

This species is distinguished by the tripartite segment IX, the very short paraproctal process, the very long inferior appendages with large, club-shaped dorsal branch, and the coxopodites densely covered by small spines on the ventral surface.

Male genitalia (Fig. 1-3). In lateral view, sternite IX forming 3 pairs prominent plates; ventral plates anteriorly conical; median plates slightly shorter than ventral plates, dorsally pointing anterad; dorsal plates nearly quadrangular with single posterodorsal and posteroventral processes. In dorsal view (Fig. 2) sternite IX producing anterad at center, immediately opposite of paraproctal process (Fig. 2). In ventral view sternite IX with short, central lobe with short marginal megasetae (Fig. 3). Long, slender, tube-shaped process originating immediately below paraproctal process possibly forming phallus (Fig. 1, 2). Pair of flat, lateral processes originate at or immediately below dorsal plates of sternite IX (Fig. 1, 2). In ventral view (Fig. 3) sternite IX narrowing centrally. Tergum IX originating from posterodorsal part of dorsal plates of sternite IX; narrow at basis; directed posterad along its length; tapering apically in lateral view (Fig. 1); wide in dorsal view (Fig. 2), slightly narrowing distally, apex truncate; with 2 pairs of setae immediately before apical margin. Superior appendages tube-shaped; basal one-third oriented posteroventrad before bending posterad; setae present at distal two-thirds. Inferior appendages 2.5 times longer than superior appendages; oriented posterad along their lengths, except slightly bending dorsad at anterior one-fifth; dividing at anterior one-fifth into dorsal branches posteriorly exceeding superior appendages, with wide, club-shaped distal two-fifths; dorsal branches divided by transversal articulation at two-fifths their lengths; sclerous process large, sharply pointing posterad, with dentose dorsal and ventral margins, apices reaching as long as apex of dorsal branch of inferior appendages. Ventral branch of inferior appendages (Fig. 1) curving ventrad before ending in coxopodites. Paraproctal process minute, as long as length of sternite IX in dorsal view (Fig. 2); oriented posterad, with small megasetae along posterior apex (Fig. 1, 2). In ventral view (Fig. 3) coxopodites narrowing posterad in lateral and ventral views (Fig. 2, 3); with short megasetae centrally on ventral surface towards harpago, delimited laterally by short setae (Fig. 3). Harpago slightly bending posteroventrad from ventral margin of coxopodites (Fig. 1); in ventral view (Fig. 3) fusing at basal one-third before dividing into pair of posterad oriented, apically inwardly curving branches.

Holotype male: VIETNAM: Bac Thai Province, Quang Chu, 24-25.v.1987, light [J. Oláh] (OPC, in alcohol). 
Etymology. kemnounga, from "khiem nhuong", meaning modest in Vietnamese, referring to the difficulties in discovering this small animal among the numerous other caddisflies in the sample.
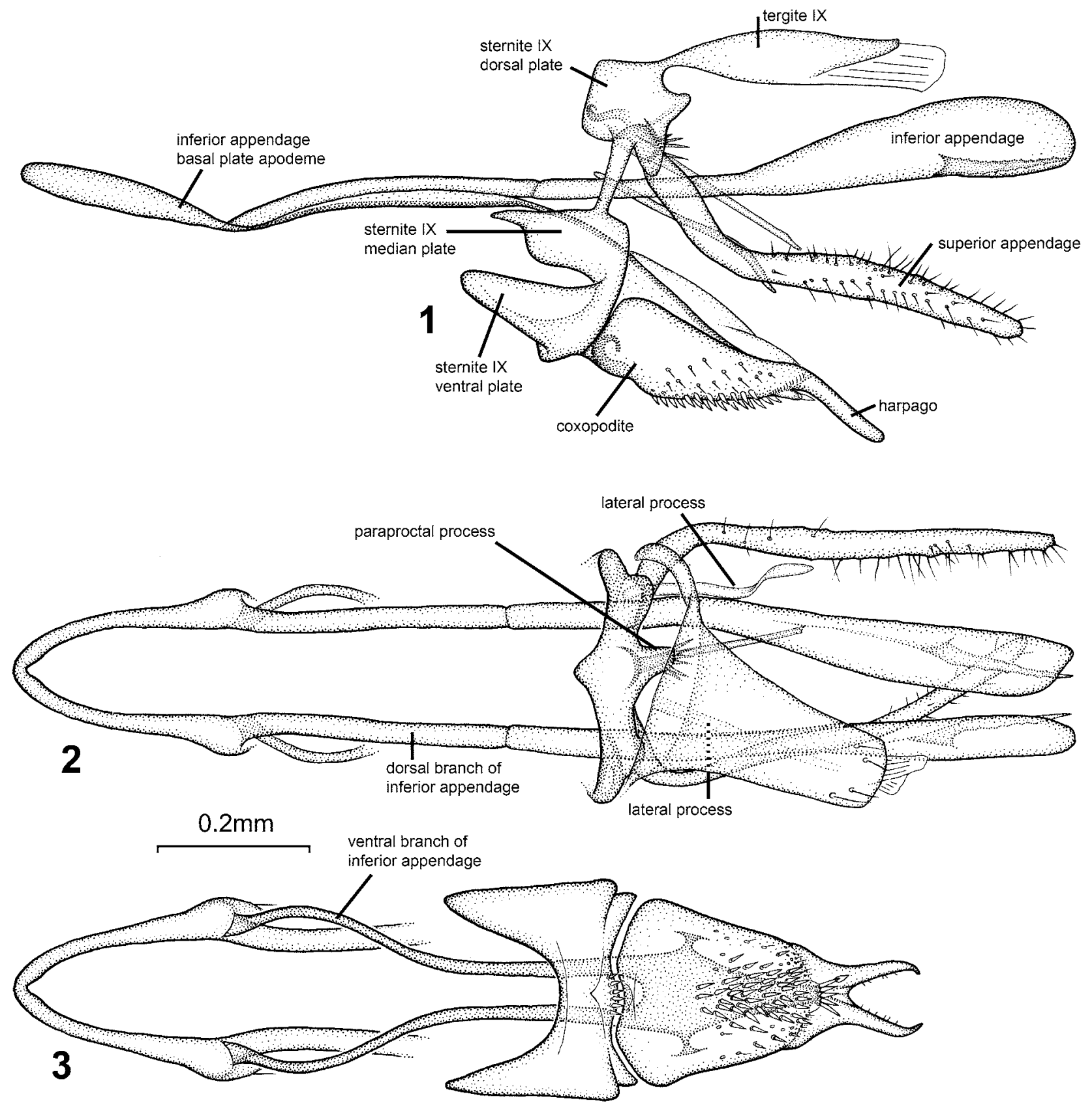

FIGURES 1-3. Tinodes kemnounga, new species, holotype. 1 - genitalia, lateral; 2 - genitalia, dorsal; 3 - genitalia, ventral. Scale bar $=0.2 \mathrm{~mm}$ refers to Fig. $1-3$.

\section{Tinodes samkuca, new species}

Fig. 4-6

This species is distinguished by the posteriorly 3-branched gonocoxite; a very long tergite IX that in dorsal view ends into a narrow, posterad oriented parallel-sided projection; and, in lateral view, a distally narrowing and sigmoid paraproctal process bearing 5 pairs strong megasetae. 

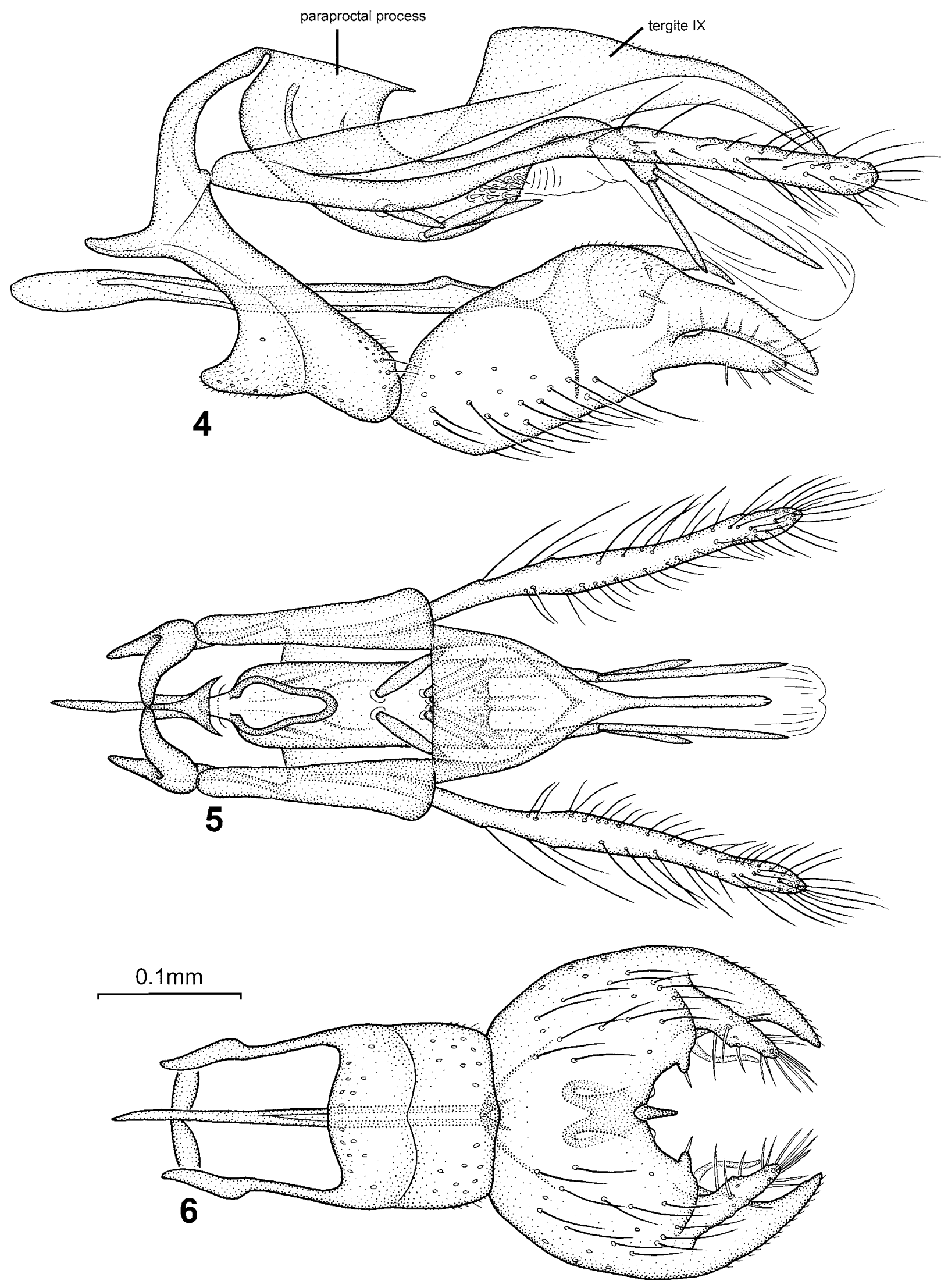

FIGURES 4-6. Tinodes samkuca, new species, holotype. 4 - genitalia, lateral; 5 - genitalia, dorsal; 6 - genitalia, ventral. Scale bar $=0.1 \mathrm{~mm}$ refers to Fig. 4-6. 
Male genitalia (Fig. 4-6). In lateral view, sternite IX with 2 anterad oriented, pointed processes ventrally and mid-height; posteroventrally produced into rounded lobes; apex of anterad oriented processes at midheight with weak suture curving ventrad to midlength of ventral face of sternite IX (Fig. 4, 6). Tergum IX originating from small knob situated immediately above mid-height; anteriorly forming straight, wide stalk in lateral and dorsal views (Fig. 4, 5); distal part broadening dorsally (Fig. 4) before producing posterad and curving ventrad. In dorsal view, anterior stalks slightly widening posteriorly; posterior part very broad basally before strongly narrowing before mid-length; apex produced into narrow, posterad oriented parallel-sided projection (Fig. 5). Superior appendages originating from bases of tergite IX; slightly sigmoid; setae restricted to distal half; slightly exceeding apex of tergite IX (Fig. 4). Inferior appendages slightly longer than superior appendages (Fig. 4); inferior appendage basal plate apodeme broad, club-shaped in lateral view (Fig. 4); very slender, needle-shaped in dorsal and ventral views (Fig. 5, 6); posterior parts broadly claw-shaped in lateral view; apices slightly pointing ventrad; with 2 small, laterad oriented megasetae on lateral surfaces; in ventral view apices very slender, oriented mediad before curving posterad, visible medially of harpagones (Fig. 6). Paraproctal process originating from dorsal apex of sternite IX; sigmoid in lateral view (Fig. 4); dorsobasal margin straight, produced posterad (Fig. 4), pyriform in dorsal view (Fig. 5); basal part oriented ventrad before slightly looping dorsad; with 3 pairs megasetae in row along ventral margin, followed by small megasetae in ventral group; divided into 2 tuboid branches (Fig. 5) with 2 pairs long, apical megasetae (Fig. 4, 5). Gonocoxites with basal half fused ventrally (Fig. 6); coxopodites divided apically into large dorsal and short ventral branches; harpagones situated between coxopodite branches (Fig. 4, 6); dorsal branches without setae; ventral branches with single apical, mediad oriented seta. Harpagones nearly as long as dorsal branch of coxopodites, covered by strong setae (Fig. 4, 6).

Holotype male: MALAYSIA: Perak, Halong str., ix-x.1993, light [G. S. Robinson] (OPC, in alcohol).

Etymology. samkuca, from "samkuc", meaning shrunk in Vietnamese, referring to the small size of this species.

\section{Tinodes caolana, new species}

Fig. 7-9

This species is distinguished by the shape of the paraproctal process which is divided into a high and narrow central branch and a pair of slightly shorter lateral branches with 9 pairs of megasetae; the basal part being very thick, with a large membranous area.

Male genitalia (Fig. 7-9). In lateral view, sternite IX with 2 small anterad oriented, rounded processes ventrally and at mid-height; posteroventrally broadly produced into rounded lobes. Tergum IX originating from superior appendages below mid-height of sternite IX; anteriorly forming straight, narrow stalk in lateral and dorsal views (Fig. 7, 8); distal part broadening dorsally (Fig. 7) before producing and narrowing posterad before slightly curving ventrad. In dorsal view, anterior stalks about equally broad before ending into anterior rays of posterior part; posterior part distally fused into plate-like apex with lateral expansions and central posterior lobe (Fig. 8). Superior appendages originating from sternite IX below mid-height; slightly sigmoid; club-shaped; broadest at distal half; setae restricted to distal two-thirds (Fig. 7, 8). Inferior appendages slightly longer than superior appendages (Fig. 7); inferior appendage basal plate apodeme broad, club-shaped in lateral view (Fig. 7); very slender, needle-shaped in ventral view (Fig. 9); posterior parts with 2-branched claws (Fig. 7); dorsal apices hooking ventrad, ventral apices pointing posteroventrad; without setae on lateral surfaces; in ventral view with right and left branches situated very closely, visible between harpagones (Fig. 9). Paraproctal process originating from dorsal apex of sternite IX; divided into central branch and pair of lateral branches. Central branch sigmoid and very broad in lateral view, angling posterad before mid-length (Fig. 7), slender in dorsal view (Fig. 8). Lateral branches slightly sigmoid (Fig. 7), nearly as long as central branch; 

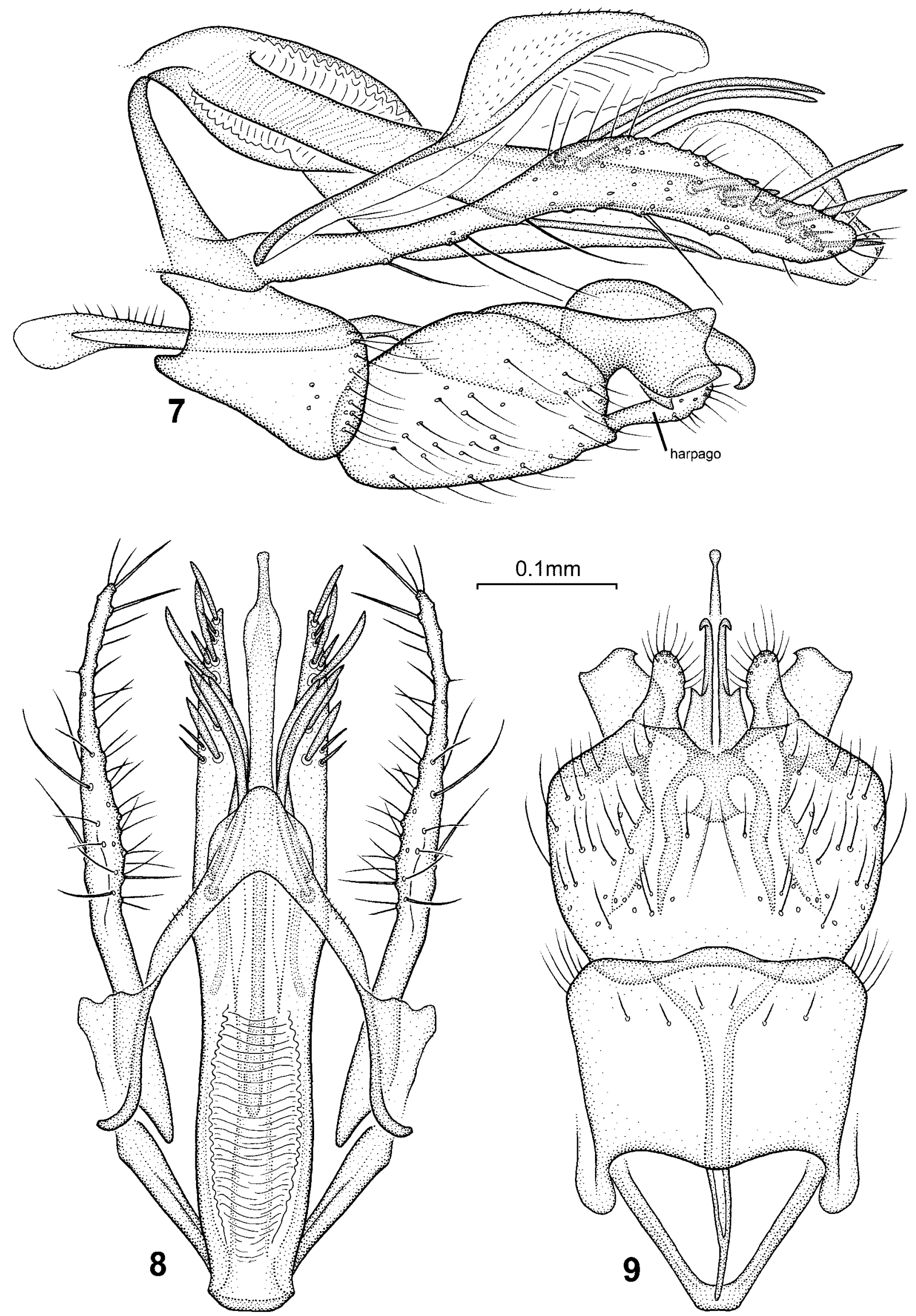

FIGURES 7-9. Tinodes caolana, new species, holotype. 7 - genitalia, lateral; 8 - genitalia, dorsal; 9 - genitalia, ventral. Scale bar $=0.1 \mathrm{~mm}$ refers to Fig. 7-9. 
with 3 pairs very long megasetae at dorsal and ventral margins originating immediately after mid-length of branch; 6 pairs shorter megasetae located in row along dorsal apical margin (Fig. 7). Basal part of paraproctal process broad (Fig. 7, 8) with large membranous areas; about parallel-sided in dorsal view (Fig. 8); in lateral view with convex dorsal margin. Coxopodites oval in lateral view, with prominent posterodorsal branch incised at ventrobasal margins and posterior apical margins (Fig. 7); in ventral view fusing mesally at basal three-fourths (Fig. 9). Harpagones setose, originating from ventrodistal corner of coxopodites; slightly clubshaped in lateral view, straight; pointing posteromesad in ventral view (Fig. 9).

Holotype male: VIETNAM: Lamdong, Baoloc, Baco str., 26.x.1988, light [J. Oláh] (OPC, in alcohol).

Etymology. caolana, from "caolan", the name of a small tribe living in the area from where the species was collected.

\section{Tinodes gapbona, new species}

Fig. 10-13

This species is distinguished by the shape of the paraproctal process that is divided into a main central branch that is sub-divided before apex, and a short pair of lateral branches with ventral megasetae in apical group. The shape of the posterior branches of the inferior appendage are divided into short up-curving ventral tooth and long, ventrally looping dorsal branch. Tinodes gapbona, new species is similar to Tinodes achaemenides Malicky \& Chantaramongkol 1996 with an asymmetrical paraproctal process forming a sheath around a pair of sclerous processes, similar inferior appendages, and a pair of ventrad curving apical processes on the coxopodite.

Male genitalia (Fig. 10-13). In lateral view, sternite IX with 1 pair of finger-like, anterad oriented processes above the anterad produced anteroventral corner; posteroventrally produced into long, rounded lobes. Tergum IX originating from basis of superior appendages well below mid-height of sternite IX; ventral margins straight along their lengths (Fig. 10); irregularly broadening distally in lateral view (Fig. 10); with central, U-shaped incision at posterior margin in dorsal view (Fig. 12). Superior appendages originating well below mid-height of sternite IX; club-shaped; slightly bent posterad immediately after mid-length (Fig. 10); diverging in dorsal view (Fig. 12). Inferior appendages slightly longer than superior appendages (Fig. 10); inferior appendage basal plate apodeme slender, with club-shaped anterior apex in lateral view (Fig. 10); very slender, needle-shaped in dorsal and ventral views (Fig. 12, 13); posterior part 2-branched, claw-like (Fig. 10); dorsal apex strongly looping ventrad, with 2 pairs setae near margin on lateral surface; ventral apex pointing posterad; in ventral view visible as single, slender process along longitudinal axis of genitalia (Fig. 13). Paraproctal process complicated, originating from dorsal apex of sternite IX; divided into long central branch and pair of shorter lateral branches. Central branch proximally straight and distally curving ventrad in lateral view (Fig. 10); main part forming sheath with central, dorsad curving tube and pair of long, pointed, asymmetrical sclerous processes (Fig. 10, 11, 12). Lateral branches of paraproctal process oriented ventrad before curving posterad at mid-length (Fig. 10); densely covered by stout, ventrad and laterad oriented megasetae at apex (Fig. 10); in dorsal view left and right branches converging towards mid-length before diverging apices (Fig. 12). Coxopodites oval in lateral view (Fig. 10); in ventral view fused mesally at basal three-fourths (Fig. 13); apices with lateral, finger-like process with short setae along mesal margin (Fig. 13); additional slender process originating from basis of harpagones being sigmoid in ventral view (Fig. 13) and strongly looping ventrad in lateral view (Fig. 10). Harpagones setose, originating from apex of coxopodites; slightly club-shaped in lateral view, straight (Fig. 10); in ventral view (Fig. 13) cone-shaped, slightly directed mesad (Fig. 13).

Holotype male: VIETNAM: Hoabinh towards Dabac, 21.x.1986, light [J. Oláh] (OPC, in alcohol).

Etymology. gapbona, from "gap bon", meaning four fold in Vietnamese, referring to the fourfold appearance of the gonocoxite and paraproctal process. 


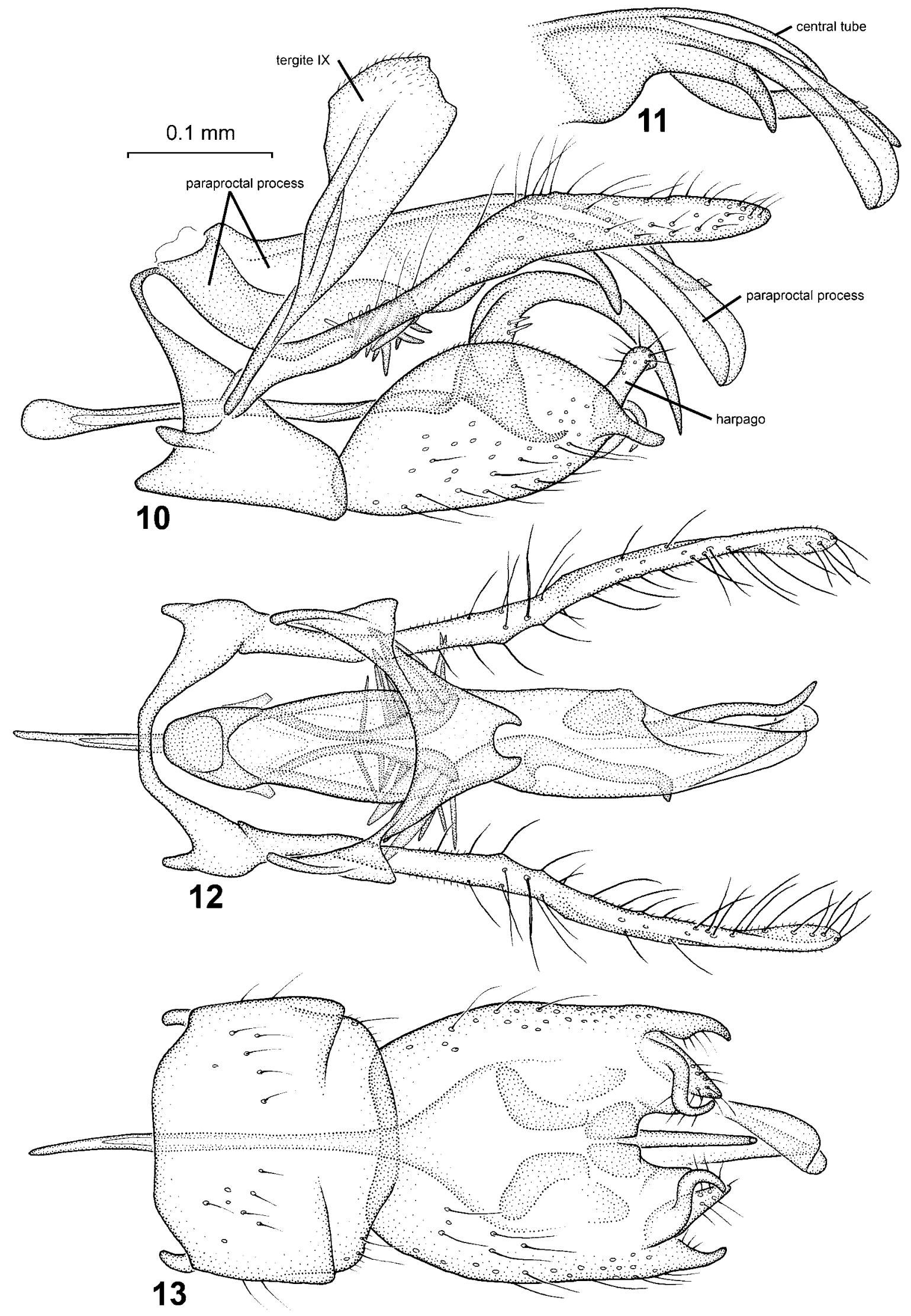

FIGURES 10-13. Tinodes gapbona, new species, holotype. 10 - genitalia, lateral; 11 - detail of posterior part of paraproctal process, lateral; 12 - genitalia, dorsal; 13 - genitalia, ventral. Scale bar $=0.1 \mathrm{~mm}$ refers to Fig. 10-13. 


\section{Tinodes kebala, new species}

Fig. 14-17

This species is distinguished by the strongly dorsally expanded tergite IX with posterolateral band of posterad oriented megasetae; and in the paraproctal process chaetotaxy involving an anterior pair of extremely long megasetae that are directed dorsad and loop mediad over tergite IX, and a series of shorter megasetae of different thickness along the lateral margin.

Male genitalia (Fig. 14-17). In lateral view, sternite IX with 1 pair sharply triangular, anterad oriented processes at anteroventral corner (Fig. 14); posteroventrally strongly produced into long, rectangular lobes. Tergite IX originating from dorsal basis of superior appendages about at mid-height of sternite IX; ventral margin weakly concave along its length (Fig. 14); developing into large dorsal, rectangular process and bifid apex (Fig. 14, 15); dorsal process with series of short megasetae in band immediately before posterior margin (Fig. 14); apices with laterad oriented spine (Fig. 15). Superior appendages originating at about mid-height of posterior margin of sternite IX; slightly laterally flattened; with setae confined to distal two-thirds; slightly bent posterad immediately after mid-length (Fig. 14); diverging in dorsal view (Fig. 15). Inferior appendage slightly longer than superior appendages (Fig. 14); inferior appendage basal plate apodeme slender, with gradually widening anterior apex in lateral view (Fig. 14); very slender, needle-shaped in dorsal and ventral views (Fig. 15, 17); posterior part 4-branched in lateral view, (Fig. 14); dorsal branch broadest with rounded apex; with 2 pairs megasetae at lateral surfaces; ventral branch forming ridge on coxopodite; in ventral view visible as single, slender process along longitudinal axis of genitalia (Fig. 17). Paraproctal process complicated, originating from dorsal apex of sternite IX; divided into long central branch and pair of slightly longer lateral branches. Central branch proximally straight with ventrad bending apex in lateral view (Fig. 14); main part forming sheath with central, dorsad curving tube and apparently single long, pointed, sclerous processes on left side (Fig. 14, 15). Lateral branches of paraproctal process straight along their lengths (Fig. 10); running parallel apicad (Fig. 16); anterior pair of megasetae extremely long, proximally oriented anterodorsad before curving dorsad and looping mesad and crossing over tergite IX (Fig. 14, 15, 16); 2 pairs very thick megasetae present at dorsal margin further distally (Fig. 14, 16) followed by lateral row of about 8 megasetae of various thickness (Fig. 14, 16). Coxopodites oval in lateral view (Fig. 14); ventrally fused mesally before half-length (Fig. 17); ventral apices with irregular surfaces (Fig. 14, 17); apical, smooth processes present immediately above ventral apices, oriented posteromesally, without setae (Fig. 14, 17). Harpagones (Fig. 14, 17) very short, setose.

Holotype male: MALAYSIA: Perak, Halong str., 19.xi.1993, light [G. S. Robinson] (OPC, in alcohol).

Etymology. kebala, from "kebala" meaning single in Sanskrit, referring to the single, prominent dorsal lobe of tergite IX.

\section{Tinodes dactringa, new species}

Fig. 18-20

This species is distinguished by the strongly posterad prolonged tergite IX armed with long apical megasetae; the long, gently ventrally curved dorsal branch of the paraproctal process and the shorter ventral branch of paraproctal process with thin apical megasetae; the very broad posterior part of the inferior appendage with 1 pair of dorsal arms and a ventral plate. It resembles Tinodes jicha Malicky \& Chantaramongkol 1989 and Tinodes wodgabay Malicky \& Chantaramongkol 1989 in the genital shape, especially the shape of the gonocoxites in lateral view, and the presence of a well developed posteroventral branch of the inferior appendage resembling that of $T$. dactringa, new species. 

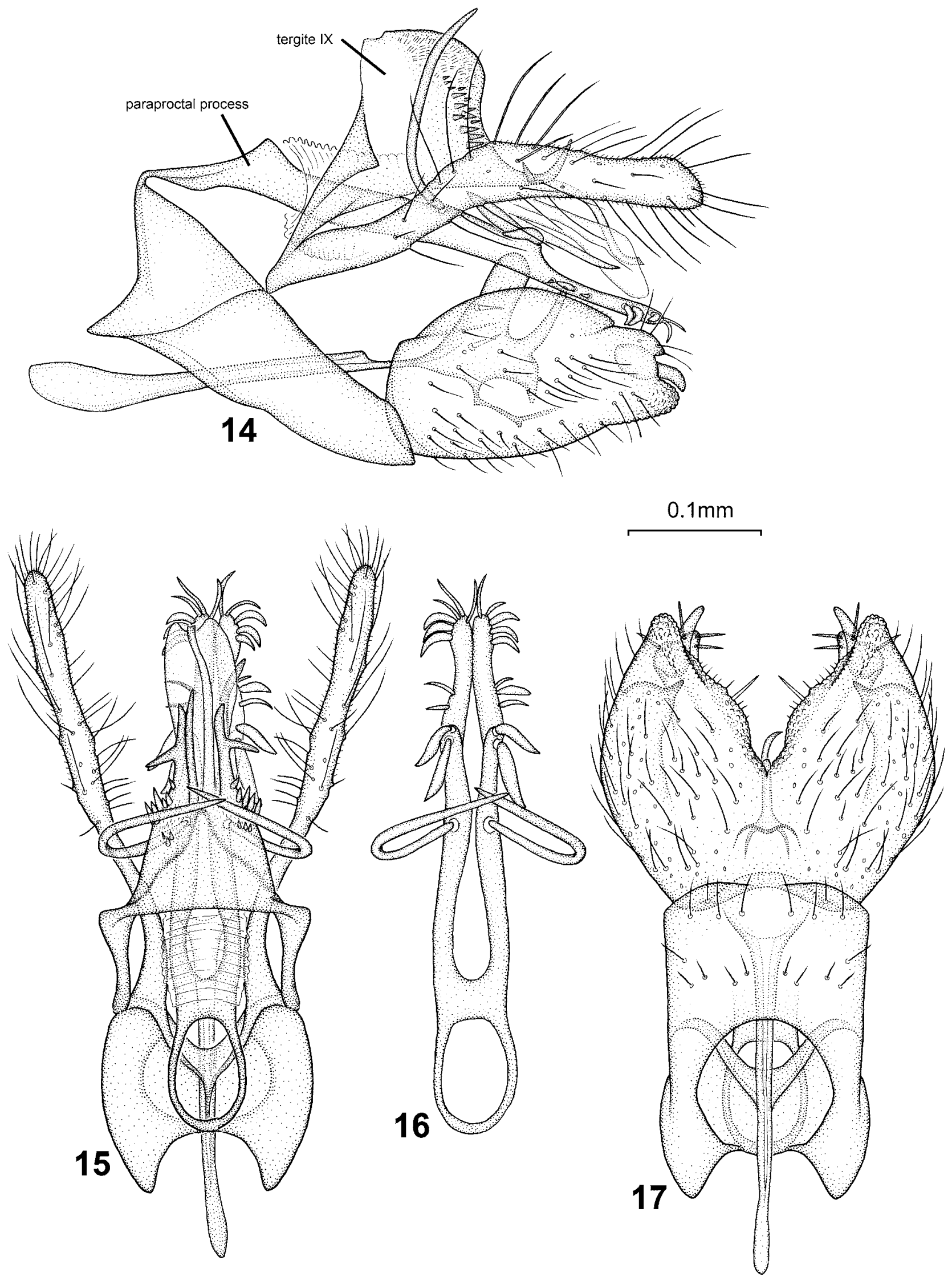

FIGURES 14-17. Tinodes kebala, new species, holotype. 14 - genitalia, lateral; 15 - genitalia, dorsal; 16 - paraproctal process, dorsal; 17 - genitalia, ventral. Scale bar $=0.1 \mathrm{~mm}$ refers to Fig. $14-17$. 

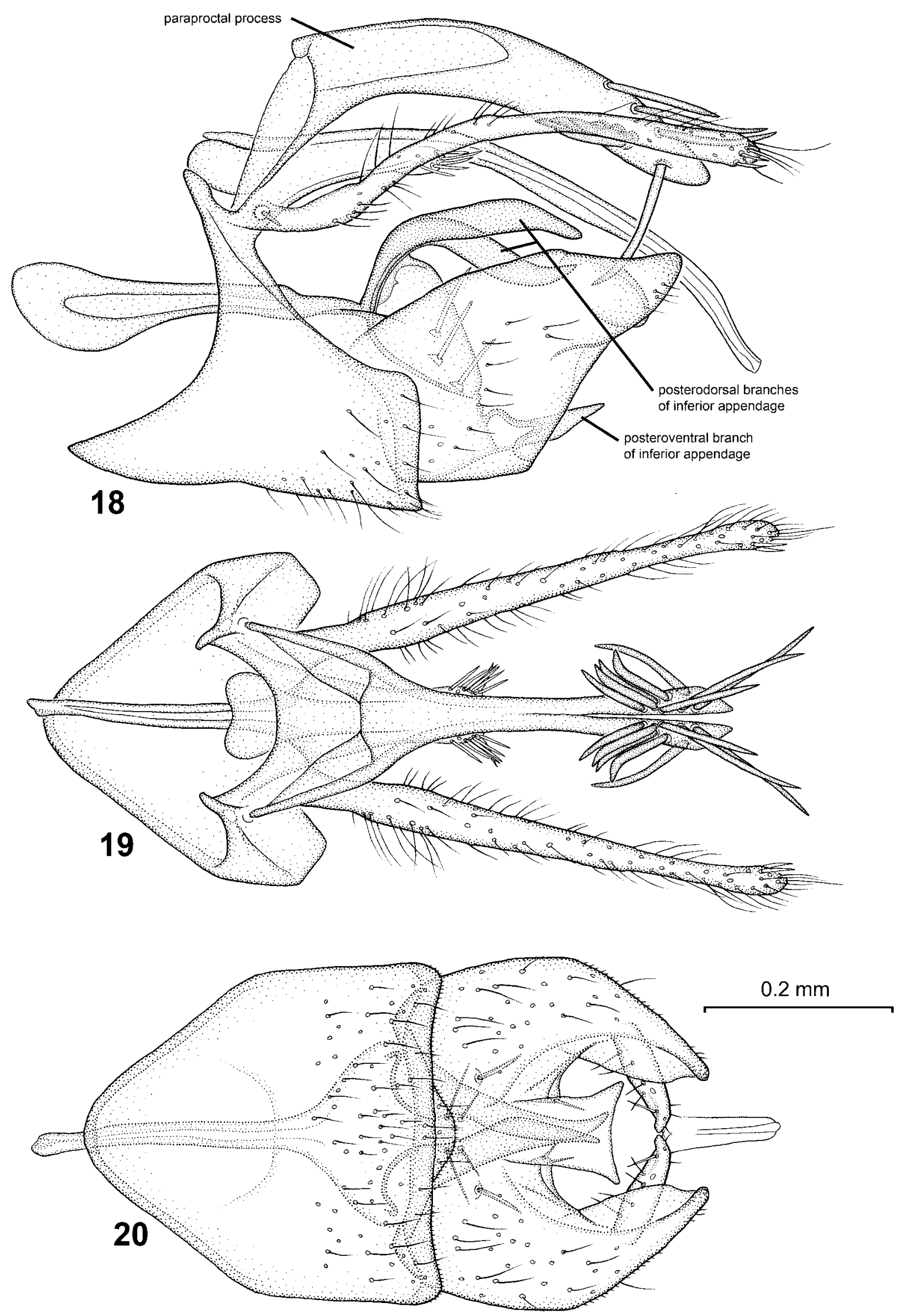

FIGURES 18-20. Tinodes dactringa, new species, holotype. 18 - genitalia, lateral; 19 - genitalia, dorsal; 20 - genitalia, ventral. Scale bar $=0.2 \mathrm{~mm}$ refers to Fig. $18-20$. 
Male genitalia (Fig. 18-20). In lateral view, sternite IX with 1 pair sharply triangular, anterad oriented processes at anteroventral corner (Fig. 18); posteroventrally produced into broad rectangular lobes. Tergite IX originating from dorsal basis of superior appendages well above mid-height of sternite IX; ventral margin concave along its length (Fig. 18); dorsal and ventral margins nearly parallel along its length in lateral view (Fig. 18); in dorsal view vase-shaped with deeply cleft apex (Fig. 19); about 8 pairs long megasetae present on apex (Fig. 18, 19). Superior appendages originating from near dorsal apices of sternite IX (Fig. 18); sigmoid in lateral view and straight in dorsal view (Fig. 18, 19); cylindrical along their lengths; exceeding posterior apex of paraproctal process and gonocoxites (Fig. 18); setae present along their lengths. Inferior appendage as long as superior appendages (Fig. 18); basal plate apodeme slender widening into club-shaped anterior apex in lateral view (Fig. 18); slender and narrowing anterad in dorsal and ventral views (Fig. 19, 20). Inferior appendage widening posterad, with 1 pair long, thick posterodorsal branches distally curving posterad (Fig. 18) and converging mesad in ventral view (Fig. 20); posteroventral branch of inferior appendage about as long as thickness of tergite IX in lateral view (Fig. 18), apically pointed; in ventral view (Fig. 20) forming plate with slightly producing posterolateral corners; surface of inferior appendage, between posterodorsal and posteroventral branches with 3 pairs long megasetae orienting dorsolaterad (Fig. 18, 20). Paraproctal process forming slightly ventrad curving dorsal branch, about as long as superior appendages (Fig. 18), and pair of ventral branches about one-third as long as dorsal branch, running parallel with dorsal branch; dorsal branch without setae; ventral branches with pair of ventrolateral megaseta at bases behind basis of superior appendages, and thick setae at lateral part of apices (Fig. 18, 19). Coxopodites nearly triangular in lateral view (Fig. 18); ventrally fused mesally before half-length (Fig. 20); apices triangular in lateral view (Fig. 18); in ventral view (Fig. 20) generally broad before knob-shaped, posteromesad oriented apices. Harpagones not seen in lateral view; setose; oriented mesad with tangent apices (Fig. 20).

Holotype male: VIETNAM: Moc Chau, 26.x.1986 [J. Oláh] (OPC, in alcohol).

Paratypes: same data as holotype -4 males and 3 females (OPC, in alcohol); same, except in NRM.

Etymology. dactringa, from dactring, meaning typical in Vietnamese, referring to this species as the first Tinodes species observed by one of us (János Oláh) from outside the West Palaearctic Region, and being unique from the species in that region.

\section{Tinodes suksa, new species}

Fig. 21-23

This species is distinguished by the posteriorly produced sternite IX; the very long and apically dividing paraproctal process originating from sternite IX well below mid-height of genitalia and bearing 1 pair of very large posterolaterad megasetae at mid-length; and the extremely narrow tergite forming a narrow band along the length above the paraproctal process.

Male genitalia (Fig. 21-23). In lateral view, sternite IX ventral parts strongly producing posterad, dorsal parts expanding anterad before ending in paraproctal process below mid-height of genitalia (Fig. 21); in ventral view nearly oval, with slightly incising anterior apex (Fig. 23). Tergite IX long, originating from dorsal basis of superior appendages; sigmoid, narrow tuboid laterally, continuing dorsally above paraproctal process (Fig. 21, 22); in dorsal view slightly diverging before fusing as far out as apices of coxopodites (Fig. 21, 22); without setae or megasetae. Superior appendages originating from dorsal-most part of sternite IX; undulating distad; about 2 times wider than tergite IX along its length in lateral view (Fig. 21); in dorsal view widest at mid-length (Fig. 22); setae restricted to distal two-fifths. Inferior appendage as long as superior appendages (Fig. 18); basal plate apodeme gradually widening anterad into slightly up-curving, club-shaped apex (Fig. 21); in ventral view (Fig. 23) narrow before ending in anterior spine (Fig. 23); posterior part ending in coxopodite basis (Fig. 21). Paraproctal process basally wide in lateral view (Fig. 21); orienting anterodorsad 


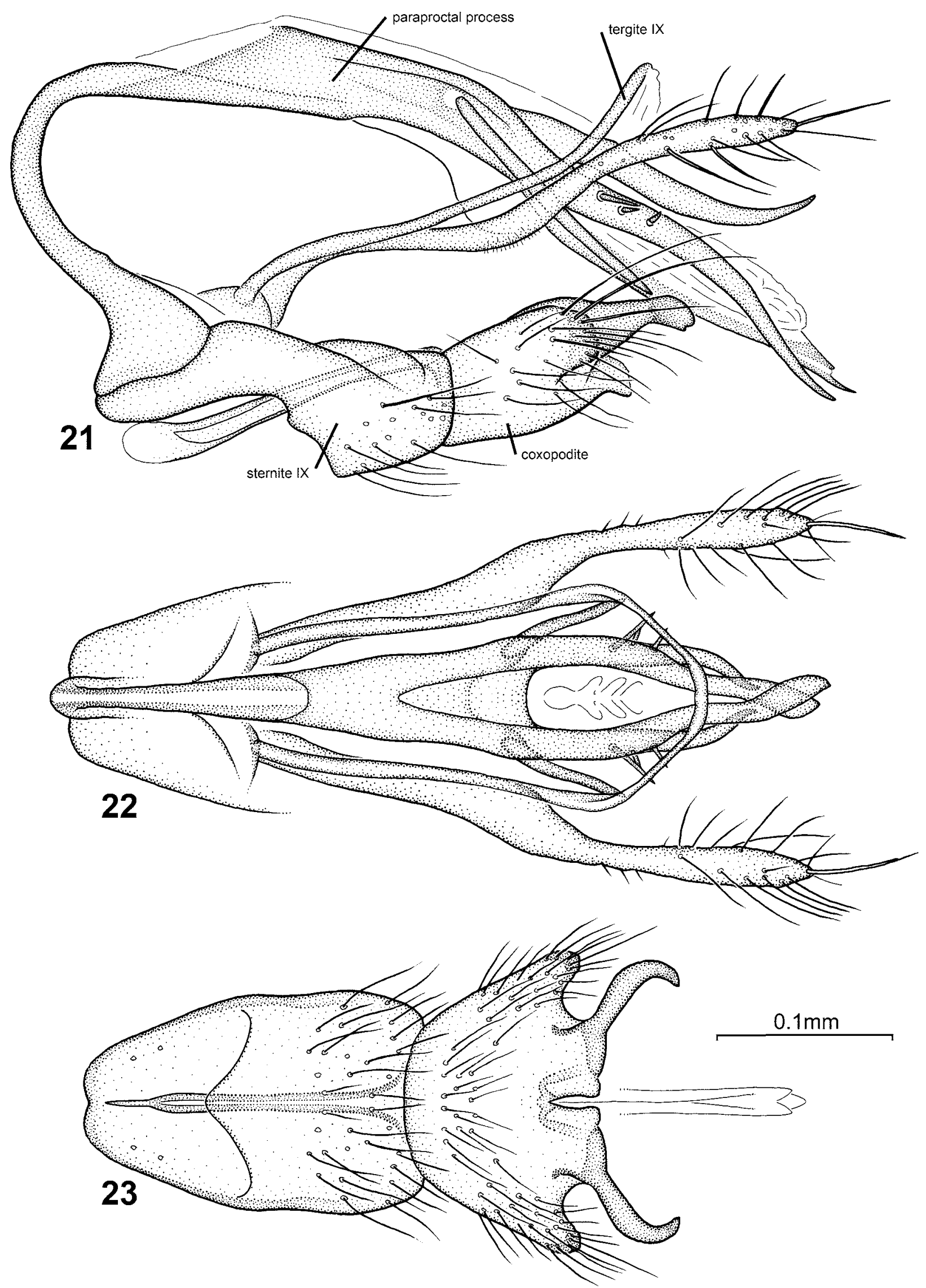

FIGURES 21-23. Tinodes suksa, new species, holotype. 21 - genitalia, lateral; 22 - genitalia, dorsal; 23 - genitalia, ventral. Scale bar $=0.1 \mathrm{~mm}$ refers to Fig. 21-23. 
before looping posteroventrad; divided into dorsal and ventral processes around mid-length its length (Fig. 22); dorsal process laterally narrowly bifid from midlength its length; ventral process longer than dorsal process, widely bifid immediately after large lateral megasetae (Fig. 22); dorsal process smooth; ventral process with 1 pair very large, posteroventrad orienting megasetae, followed by lateral pair of rows of 3 short megasetae; branches of dorsal process curving dorsomesad apically; branches of ventral process oriented posteroventrad and crossing apically (Fig. 22). Coxopodites as broad as posterior part of sternite IX in lateral view (Fig. 21), dorsal and ventral margins nearly parallel (Fig. 21); ventrally fused mesally at three-fourths their length (Fig. 23); apically separated by narrow slit; producing laterally into posterolaterad setose lobes; with 1 pair prominent, smooth processes originating from posterior apices, in ventral view directed laterad before mesad curving apices (Fig. 23). Harpagones absent.

Holotype male: MALAYSIA: Perak, Halong str., 29.xi.1993, light [G. S. Robinson] (OPC, in alcohol).

Paratypes: same data as holotype, except 8.xii.1993 - 1 male; same, except in NRM; MALAYSIA: Pahang Genting Tea Estate, 2000 ft., xi.1981, Malaise trap by stream [K. R. Truck] - 5 males; same, except 4 males in NRM.

Etymology. suksa, from suksa, meaning thin in Sanskrit, referring to the slender body and genitalia of this species.

\section{Acknowledgement}

We are very thankful to Andrea Klintbjer (NRM) for illustrating these new species.

\section{References}

Banks, N. (1937) Philippine neuropteroid insects. Philippine Journal of Science, 63, 125-174.

Iwata, M. (1928) Five new species of trichopterous larvae from Formosa. Annotationes Zoologicae Japanenses, 11, 341351.

Johanson, K.A. (2001) Two new Tinodes from Sabah, Malaysia (Trichoptera, Psychomyiidae). Tijdschrift voor Entomologie, 144, 247-251.

Johanson, K.A. \& Oláh, J. (2007) Description of fourteen new Tinodes species from East Africa (Trichoptera: Psychomyiidae). Insect Systematics and Evolution, 38, 37-404.

Kimmins, D.E. (1955) Results of the Oxford University expedition to Sarawak, 1932. Order Trichoptera. Journal of Sarawak Museum, 6, 374-442.

Malicky, H. (1995) Weitere neue Köcherfliegen (Trichoptera) aus Asien. Braueria, 22, 11-26.

Malicky, H. (1998) Köcherfliegen (Trichoptera) von Java und Sumatra, mit Revision einiger Ulmer-Typen aus dem Hamburger Museum. Linzer biologische Beiträge, 30, 795-814.

Malicky, H. 2004a. Atlas of European Trichoptera. Dordrecht: Springer-Verlag. 359 pp.

Malicky, H. 2004b. Neue Köcherfliegen aus Europa und Asien. Braueria, 31, 36-42.

Malicky, H. \& Chantaramongkol, P. (1989) Beschreibung von neuen Köcherfliegen (Trichoptera) aus Thailand und Burma. Entomologische Berichte Luzern, 22, 117-126.

Malicky, H. \& Chantaramongkol, P. (1993) Neue Trichopteren aus Thailand. Teil 1: Rhyacophilidae, Hydrobiosidae, Philopotamidae, Polycentropodidae, Ecnomidae, Psychomyidae, Arctopsychidae, Hydropsychidae. Linzer biologische Beiträge, 25, 433-487.

Malicky, H. \& Chantaramongkol, P. (1996) Neue Köcherfliegen aus Thailand (Trichoptera). Entomologische Berichte Luzern, 36, 119-128.

Malicky, H. \& Chantaramongkol, P. (2003) Vierzehn neue Köcherfliegen aus Thailand (Insecta, Trichoptera). Linzer biologische Beiträge, 35, 915-925.

Mey, W. (1990) Neue Köcherfliegen von den Philippinen (Trichoptera). Opuscula zoologica fluminensia, 57, 1-19.

Mey, W. (1995) Beiträg zur Kenntnis der Köcherfliegenfauna der Philippinen, I (Trichoptera). Deutsche Entomologische Zeitschrift, N. F., 42, 191-209.

Mey, W. (1998a) Contribution to the knowledge of the caddisflies of the Philippines, 2. The species of the Mt. Agtuuganon Range on Mindanao (Insecta: Trichoptera). Nachrichten des Entomologischen Vereins Apollo, Supplement, 17, 
537-576.

Mey, W. (1998b) Contribution to the knowledge of the caddisfly fauna of the Philippines, III (Insecta: Trichoptera). Entomofauna, 19, 1-32.

Morse, J.C. (1999) Trichoptera World Checklist. Available from: http://entweb.clemson.edu/database/trichopt/index.htm (accessed: 17 July 2007).

Navás, L. (1932) Comunicaciones entomológicas. 14. Insectos de la India. 4.a serie. Revista de la [Real] Academia de Ciencias Exactas Fisico-Quimicas y Naturales de Zaragoza, 15, 11-41.

Nielsen, A. 1957. A comparative study of the genital segments and their appendages in male Trichoptera. Biologiske Skrifter, 8 (5), 1-159.

Oláh, J., Johanson, K.A. \& Barnard, P.C. (2008). Revision of Oriental and Afrotropical Cheumatopsyche species (Hydropsychidae, Trichoptera). Zootaxa, 1738, 1-171.

Schmid, F. 1972. Sur quelques nouvelles Psychomyiines tropicales (Trichoptera: Psychomyiidae). Naturaliste canadien, $99,143-172$.

Ulmer, G. (1910) Ueber einige von Herrn E. Jacobson auf Java gesammelte Trichopteren. Notes from the Leyden Museum, 32, 47-66.

Ulmer, G. (1927) Einige neue Trichopteren aus Asien. Entomologische Mitteilungen, 16, 172-182.

Ulmer, G. (1930) Trichopteren von den Philippinen und von den Sunda-Inseln. Treubia, 11, 373-507.

Ulmer, G. (1951) Köcherfliegen (Trichopteren) von den Sunda-Inseln (Teil I). Archiv für Hydrobiologie, Supplement, 19, $1-528$. 